\title{
Single Cellular Algae Digestive Supplement Designed by Yeast \& Lactobacillus Rearranged Leukocyte Subsets through Activation of Complement Components
}

\author{
Hitoshi Kubota ${ }^{1,2 *}$, Nurmuhamamt Amat ${ }^{3}$, Dilxat Yimit ${ }^{3}$, Parida Hoxur ${ }^{4}$, \\ Nobuo Yamaguchi1,2 \\ ${ }^{1}$ Ishikawa Natural Medicinal Products Research Center, Ishikawa, Japan \\ ${ }^{2}$ Department of Fundament Research for CAM, Kanazawa Medical University, Ishikawa, Japan \\ ${ }^{3}$ Traditional Uighur Medicine Department, Xinjiang Medical University, Urumqi, China \\ ${ }^{4}$ Traditional Chinese Medicine Hospital, Xinjiang Medical University, Urumqi, China \\ Email: serumaya@kanazawa-med.ac.jp
}

Received 14 May 2015; accepted 25 August 2015; published 28 August 2015

Copyright (C) 2015 by authors and Scientific Research Publishing Inc.

This work is licensed under the Creative Commons Attribution International License (CC BY). http://creativecommons.org/licenses/by/4.0/

c) (i) Dpen Access

\section{Abstract}

A plant fermentation was carried out by Yeast and Lactobacilli against single cellular algae $(f$ Chlorella). These materials were proved by as safe in animal safety experiment. We sought to look into changes of immune-competent cells that commonly utilized $\boldsymbol{f}$-Chlorella including after administration of immno-suppressed animals. The effects by $f$-Chlorella on the regurational effect to the host were measured. Our results showed that $f$-Chlorella regulated the level of lymphocytes, while conventional-Chlorella worked to adjust the level of granulocytes. In our clinical study with 20 healthy volunteers, granulocyte and lymphocyte ratio was obtained as neutral in the peripheral blood. In rodents, immune-compromised host as well as normal animal were prepared with cancer chemotherapeutic agent (Mytomycin-C), and then tried to rescue the immune-competent rebel. Our observations showed that both Chlorella derivatives regulated in number and functions. The effect was more prominent in $\boldsymbol{f}$-Chlorella than that of conventional one. We discussed the significance and mechanism of $f$-Chlorella on the level of leukocyte subsets in number and function. These effects were considered to bring the potential elevation of antibody secreting cell by the localized heamolysis in gel method. We also proposed an idea that exhibited tonic effects were brought via activating the complement components in the serum. Moreover, we tried to access further to the anti-oxidative activities of this $f$-Chlorella. This modification brought to the significant lifted up for immune competent cells and anti-oxidative activity for phagocytic cells.

"Corresponding author.

How to cite this paper: Kubota, H., Amat, N., Yimit, D., Hoxur, P. and Yamaguchi, N. (2015) Single Cellular Algae Digestive Supplement Designed by Yeast \& Lactobacillus Rearranged Leukocyte Subsets through Activation of Complement Components. Open Journal of Immunology, 5, 104-121. http://dx.doi.org/10.4236/oji.2015.53011 


\section{Keywords}

\section{Family Poaceae, Chlorella pyrenoidosa, Fermentation, Yeast, Lactobacillus, Cancer Chemotherapeutic Agent, Compromised Host, Lipidosis, Cardiovascular Disease, Diabetes Meritus, Immune Augmentation}

\section{Introduction}

In recent years, complementary and alternative medicines (CAM) have achieved more and more attentions since they are able to treat many chronic illnesses, such as fatigue syndrome that plagues the industrialized world. The present team has reported that typical styles of CAM, preparing special molecule for both digestive and easy to activated human complement component.

Beside the complement activation, we have been reported as immune-regulatory menu by hot spring hydrotherapy and acupuncture [1] [2]. About the dietary system, here we report Chlorella derivatives Dietary and fermented formula as strong inducers of acquired immunity. While the immune system is working against the local infection of pathogens, cytokine and immuno-competent cells react throughout the body in close connection to the brain, the endocrine and immune system [3]. In this study, we hypothesize that f-Chlorella may influence immuno-competent cells qualitatively and quantitatively $f$-Chlorella targeting lymphocytes based on the constitution dependent manner. $f$-Chlorella has been employed as tonic agent and the implication has little been made on the characteristics of the levels of leukocyte subset, such as granulocytes and lymphocytes. In this report, we seek to focus on the identity of $f$-Chlorella formula, comparing to another herbal medicine. The influence of f-Chlorella on leukocyte and/or lymphocyte subpopulations in human peripheral blood is also discussed. Moreover, some preliminary trial that concerns the new processing of Chlorella cells by degradation of acidophilic bacteria and yeast fungus [4]-[10] (Figure 1).

\section{Experimental Animal}

\subsection{Toxicity Test by Single and Multiple Administration}

Ten female seven-week-old ddY mice, were used for the acute oral toxicity study. The tests were carried out

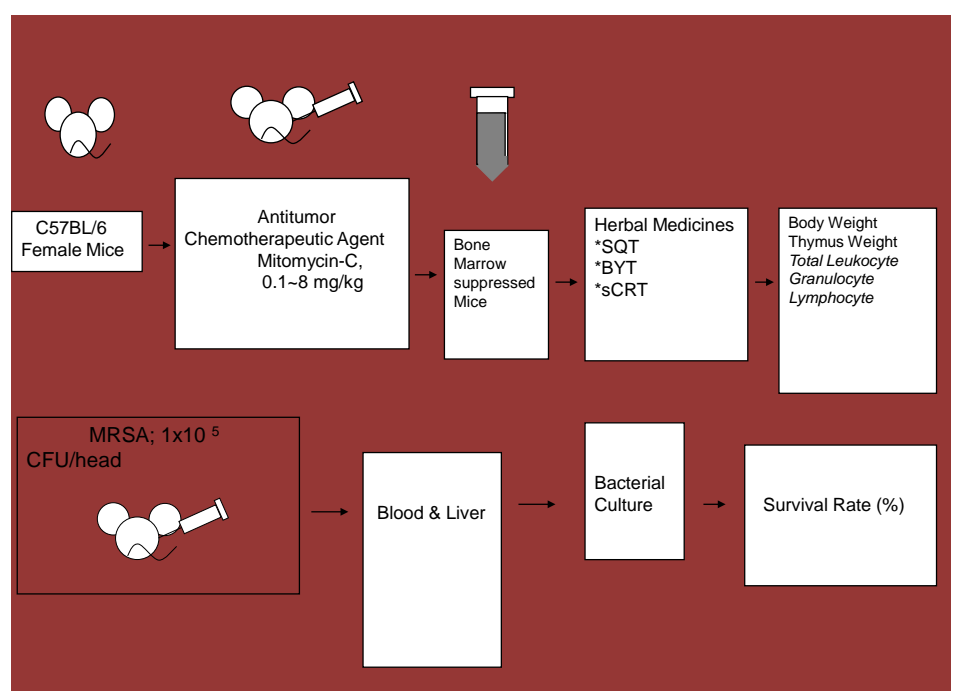

Figure 1. Experimental procedure for this animal experiments. We sampled peripheral blood from the 12 volunteers before and after hot hydro therapy, at the same time on each day, in accordance with the consideration of circadian rhythm of leukocyte. The spring quality is a weak sodium chloride with sodium carbohydrate of the water temperature $41^{\circ} \mathrm{C} \pm 1{ }^{\circ} \mathrm{C}$. During the night and in the morning of the next day, they had a bath in the hot spring two or three times, for 20 - 30 minutes each time. Time interval of blood sampling between before and after hot-spring hydrotherapy was approximately 24 hours. The total and differential leukocyte counts were measured Control waterhe automated hematology analyzer. 
according to Ethics of the Organization for Economic Co-operation and Development (OECD) Test Guideline 401. The mice were housed at $24^{\circ} \mathrm{C} \pm 1^{\circ} \mathrm{C}, 50 \%$ relative humidity. Both conventional and charged water were suspended in sterile and administered to mice in free supplemental system, calculating daily consumption. Mice were weighted at $0-7$ days after administration, and clinical observations were made once a day. Necropsy was performed on all mice seven days after administration.

\subsection{Experimental Design for Bone Marrow Suppressed Immune-Compromised Mice}

In the animal model of immuno-competency reduction, male C57BL/6J mice, aged 8 - 9 weeks, were injected with Mitomycin-C (MMC) (5 mg/kg) to inhibit the bone marrow. Then, $f$-Chlorella extracts was administered orally at a dosage of $1 \mathrm{~g} / \mathrm{kg} /$ day for five consecutive days f-Chlorella and conventional Chlorella was chosen as controls [11].

\subsubsection{Recovery of Total Leukocytes and Subsets of Leukocytes}

The bone marrow-suppressed mice were administered herbal decoction $f$-Chlorella $1 \mathrm{~g} / \mathrm{kg}$ dairy for 5 days and after 1 week later, their blood were withdrawn from their tail vain. Then, the number of leukocytes was counted in Bürker-Türk solution.

\subsubsection{A Recovery of Leukocyte Subsets by $f$-Chlorella}

Bone marrow-suppressed mice were administered with herbal decoction of $f$-Chlorella $(1 \mathrm{~g} / \mathrm{kg} /$ day $)$ for five days. One week later, the blood from their tail vain was withdrawn. Then the granulocyte and lymphocyte subsets were counted in Bürker-Türk solution.

\subsubsection{A Recovery of Macrophage Activity, Migration}

Cells from peritoneal exudates were collect from the peritoneal cavity of bone marrow-suppressed mice. Phagocytes were purified using adherent technique to get cell suspensions which contained more than $95 \%$ of phagocytes. The purified cells were loaded to the upper room of Boyden chamber to test migration ability at a concentration of $1 \times 10^{4} \mathrm{cell} / \mathrm{ml}$. Human serum treated at $56^{\circ} \mathrm{C}$ for $30 \mathrm{~min}$ was for the chemo tactic agent of mouse phagocyte [12].

\subsubsection{Recovery of Macrophage Activity, Phagocytosis}

The same cells suspension was purified by adherent technique for phagocyte, which produces cells contained more than $95 \%$ of phagocytes. The purified cells were adjusted to $1 \times 10^{4} \mathrm{cell} / \mathrm{cm}^{2}$ and mixed with latex beads that are $5 \mu \mathrm{m}$ in $f$-Chlorella, fluorescence isochianate. After $90 \mathrm{~min}$ of incubation, remained granule were washed out from the glass slide. Number of phagocytic cell and their ability to catch up the latex beads were automatically measured by ACAS system, which outputs the result in a digital form (Adherent cell activity evaluating system; Shimazu, Kyoto, Japan).

\subsubsection{Recovery of Macrophage Activity, Target Cell Killing}

The same phagocyte suspension, which contained over $95 \%$ of phagocytes, was produced by adherent technique for phagocyte. The purified cells were adjusted to $1 \times 10^{5} \mathrm{cell} / \mathrm{ml}$ to examine the macrophage activity of killing, the nitro blue tetrazolium (NBT) reduction test [13] [14].

\subsubsection{A Recovery of Lymphocyte Activity, Antibody Secreting Cell}

The bone marrow suppressed mice were administered herbal decoction of $f$-Chlorella $(1 \mathrm{~g} / \mathrm{kg} /$ day $)$ for 5 days. One week later, mice were immunized with sheep red blood cells, $\left(2 \times 10^{8} /\right.$ mouse $)$ intraperitoneally. Five days later, their spleen cells were collected. Plague-forming cells (PFC) were developed, and the ability of IgM and IgG antibody production was tested $f$-Chlorella he method reported by Jerne and Nordin [15].

\subsubsection{Positive Lymphocyte Distribution by f-Chlorella against Different Constitution}

Whole blood obtained from the subjects was washed twice with PBS. One hundred micro-liters of the suspensions were stained with $20 \mu \mathrm{l}$ of fluorescent monoclonal antibodies (anti-human $\mathrm{CD}^{+}, \mathrm{CD} 4^{+}, \mathrm{CD}^{+}, \mathrm{CD} 11 \mathrm{~b}^{+}$, $\mathrm{CD} 14^{+}, \mathrm{CD} 16^{+}, \mathrm{CD} 19^{+}$and $\mathrm{CD} 56^{+}$antibodies). Ten thousands stained cells were re-suspended in PBS to detect 
surface markers by flow cytometry (FACS Calibur; Becton Dickinson Immnocytometry Systems, CA, USA).

\subsubsection{Distribution of Cytokine Producing Lymphocytes in Different Constitution}

The blood cell suspensions were cultured with PMA (phorbol 12-myristate 13-acetate), ionomycin and BSA (bovine serum albumin) for $4-5$ hours at $37^{\circ} \mathrm{C}$. After that, the cell suspensions were stained using the monoclonal antibodies of PE-IL-4, FITC-IFN- $\gamma$ and FITC-IL- $1 \beta$. Then they were analyzed $f$-Chlorella FACScan (Becton Dickinson Co. Ltd. USA). The antibodies and reagents used in the test were purchased from Becton Dickinson Immunocytometry System (USA).

The peritoneal exudates cells were collect from the peritoneal cavity of bone marrow-suppressed mice. Cell suspensions were purified by adherent technique for phagocyte, getting a suspension which contained over 95\% of phagocytes. The purified cells were adjusted to $1 \times 10^{4} \mathrm{cell} / \mathrm{ml}$ and loaded at the upper chamber of Boyden chamber for test migration. Human serum with treated at $56^{\circ} \mathrm{C}$ for 30 min was for the chemotactic agent for mouse phagocyte.

Phagocytic activity and antibody production of macrophages were analyzed using a classical test that could test the total activity of the immune system by examine chemotaxis, phagocytosis and intracellular degradation of macrophage. For identifying antibody-forming cells, plaque-forming cells were detected using heterogeneous erythrocyte; sheep erythrocyte was a target antigen. Peritoneal macrophages were collected and purified in fetal calf serum (FCS)-coated petri-dishes. The cell population was approximately $97 \%$ uniform in function and morphology. These cells were applied to the nuclepore-membrane (pore size: $5 \mu \mathrm{m}$; Neuro Probe Co. Ltd., Cabin John MD, USA) with a chemotaxis chamber (Neuro Probe Co. Ltd.). After 90 minutes' incubation, the membrane was vigorously washed with saline $\left(37^{\circ} \mathrm{C}\right)$, fixed, and then stained with methylene blue dye. After counting under a microscope for the total field of the membrane, the average number of migrating cells was expressed as cell counts $/ \mathrm{mm}^{2}$.

The same cells suspension was purified by adherent technique for phagocyte, which contained over $95 \%$ of phagocytes. The purified cells were adjusted to $1 \times 10^{4} \mathrm{cell} / \mathrm{cm}^{2}$ and mixed with latex beads that were $5 \mathrm{um}$ in granule with $f$-Chlorella fluorescence isochianate. After $90 \mathrm{~min}$ of incubation, the remained granule were washed out from the glass slide and counting automatically by ACAS system, which outputs digital presentation, for evaluating phagocytes in number and in their ability to catch up the latex beads (Adherent cell activity evaluating system, Shimazu, Kyoto, Japan). Latex beads in $5 \mu \mathrm{m}$ with fluorescence were used to test phagocytic activity and Candida albicans was cell killing activity. A macrophage-target cell ratio of 1:10 was considered to be optimum. Ten minutes after incubating phagocytes and target cells, intracellular Candida cells were cultured on an agar dish with conventional medium 1640 until the next day to perform the colony forming assay. In this way, the phagocytic ability of the macrophages was monitored. To document intracellular killing activity, the same procedures were performed excepting that the incubation time was changed to 90 minutes.

\subsection{Antibody Forming Cell Study}

Sheep erythrocyte (SRBC), a T-dependent antigen, was used for antibody formation cell study. Ten days after tumor transplantation, each antigen was intra-peritoneally injected. After four and six days, the antibody-forming cells were detected using localized hemolysis in an agar gel. Plaque-forming cells were developed $f$-Chlorella the method of Jerne and Nordin [15].

\subsection{Anti-0xidative Effect Evaluation}

\subsubsection{Animal}

Eight week-old female C57BL/6 were purchased from Sankyo Laboratory Service Corporation (Shizuoka, Japan). All mice were kept under specific pathogen-free conditions. Mice food and distilled water were freely accessible for each mouse. Housing temperature and humidity were controlled $25^{\circ} \mathrm{C} \pm 1{ }^{\circ} \mathrm{C}$ and $60 \%$.

\subsubsection{Reagents}

As for the basic medium, HEPES buffer (HEPES $17 \mathrm{mM}$, NaCl $120 \mathrm{mM}$, Glucose $5 \mathrm{mM}$, KCl $5 \mathrm{mM}, \mathrm{CaCl}_{2} 1$ $\mathrm{mM}, \mathrm{MgCl}_{2} 1 \mathrm{mM}$ ) was prepared and sterilized by filtration. Phorbol 12-myristate 13-acetate (PMA, Sigma, USA) was diluted to $10^{-6} \mathrm{M}$ by dimethyl sulfoxide DMSO, Sigma, USA) and used as a stimulant for super oxide 
anion generation for murine peritoneal exudates cells. Cytochrome-c (Sigma, USA) was diluted to $1 \mathrm{mM}$ by HEPES buffer. Since cytochrome-c reduced by super oxide showed maximum absorbance at $550 \mathrm{~nm}$, we used cytochrome-c to measure the amount of super oxide anion generation through spectro-photometrical technique. Oyster glycogen (type, Sigma, USA) was diluted in the purified water $(10 \% \mathrm{w} / \mathrm{v}$, Wako, Japan) and autoclaved at $120^{\circ} \mathrm{C}$ for $20 \mathrm{~min}$. This solution was used for intraperitoneal injection to mice in order to induce peripheral neutrophils into the abdominal cavity.

\subsubsection{The Measuring the Amount of Super Oxide Anion Generated by Murine Peritoneal Exudates Cells}

Fermented Chlorella and Conventional Chlorella were orally administered to mice (500 mg/kg) for one week. Two milliliters of $10 \%$ Oyster glycogen was injected intraperitoneally 10 hours before the assay. Sufficient murine peritoneal exudative cells were induced ten hours after the stimulation. Mice were euthanized by cervical dislocation, murine peritoneal exudates cells (PEC) suspension was centrifuged twice for 5 minutes at $1500 \mathrm{rpm}$ at $4^{\circ} \mathrm{C}$. Then PEC was prepared to $1 \times 10^{6}$ cells / $\mathrm{ml}$ of HEPES buffer. One hundred micro liters of cytochrome-c and $10 \mu \mathrm{l}$ of PMA were added to the cell suspension and this was incubated for 20 minutes at $37^{\circ} \mathrm{C}$. The reaction mixture was then centrifuged for 10 minutes at $1500 \mathrm{rpm}, 4^{\circ} \mathrm{C}$. An OD of supernatant was measured at both 550 $\mathrm{nm}$ and $540 \mathrm{~nm}$, the amount of generated super oxide anion was shown in the formula; increased absorbance at $550 \mathrm{~nm}\left(\triangle \mathrm{A}_{550-540}\right) / 19.1 \times 10^{3}(\mathrm{mmol} / \mathrm{ml})$. In order to ensure if we really measured the amount of generated super oxide anion or not, we tried to add super oxide anion dismutase (SOD), an enzyme for its anti-oxidative effect, into our experimental system. The result was as expected that the reduction of cytochrome-c was inhibited after the addition of SOD. This showed us that our experimental system could be used properly for measuring the amount of generated super oxide anion [4].

\section{Clinical Findings}

\subsection{Volunteers and Evaluation Methods}

Twenty healthy volunteers aged from 21 to 70 years for both sex were recruited and were administered f-Chlorella for 30 days. Fifteen milliliters of blood were drawn from the forearm vein one hour before the first administration of $f$-Chlorella and 30 days after the last $f$-Chlorella administration (day 30). All volunteers provided informed consent prior to participation for this trial. This study was approved by Ethics Committee of Kanazawa Medical University (Table 1).

\subsection{Chlorella Derivatives and Assessment for Host Immune Factor}

Dried formula of conventional Chlorella. and f-Chlorella in granules were chosen as representatives of f-Chlorella [12] and were chosen as controls. A dose of $5.25 \mathrm{~g}$ dried powder of each formula (SUN Chlorella Co. Ltd., KYOTO, Japan) was administered two times per day for 30 days. Physiological functions were checked and possible side effects of the drug were inquired for all the subjects to ensure the safety of the trial.

\subsection{Leukocyte Counts}

The assessments including a total number of leukocytes was ordered to count with blood chemical test for the medical diagnosis of public institution (Ishikawa Preventive Medicine Association, Ishikawa, Japan). In the differential counting, 200 cells were counted on a May-Grünewald-Gimsa stained slide, and percentages of lymphocytes and granulocytes were determined.

\subsection{Leukocyte Subset Analyses}

The assessments including a total number of leukocytes was ordered to count with blood chemical test for the medical diagnosis of public institution (Ishikawa Preventive Medicine Association, Ishikawa, Japan). In the differential counting, 200 cells were counted on a May-Grunewald-Gimsa stained slide, and percentages of lymphocytes and granulocytes were determined [14].

The whole blood obtained from the subjects was washed twice in phosphate buffered saline (PBS). One hundred micro-liters of the suspensions were stained with $20 \mu \mathrm{l}$ of fluorescent monoclonal antibodies (anti-human 
Table 1. Constitution dependent regulation of lymphocyte by Chlorella Derivatives.

\begin{tabular}{ccccc}
\hline & \multicolumn{3}{c}{ G-type individual } & \multicolumn{2}{c}{ L-type individual } \\
\cline { 2 - 5 } CD & \multicolumn{2}{c}{ Conv. Chlorella } & \multicolumn{2}{c}{$f$-Chlorella } \\
\cline { 2 - 5 } CD2 & Before (\%) & After (\%) & Before (\%) & 77.79 \\
CD4 & 63.95 & 76.91 & 60.25 & 45.14 \\
CD8 & 19.75 & 28.53 & 31.05 & 28.03 \\
CD11 & 38.44 & 40.37 & 26.52 & 70.78 \\
CD14 & 73.54 & 70.36 & 63.37 & 0.01 \\
CD16 & 0.03 & 0.05 & 0.08 & 41.23 \\
CD19 & 66.93 & 58.02 & 54.00 & 7.26 \\
CD56 & 8.33 & 8.00 & 8.39 & 1.96 \\
\hline
\end{tabular}

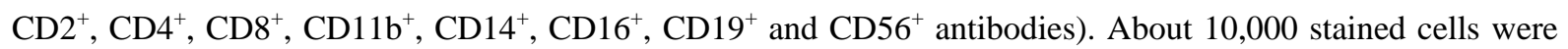
re-suspended in PBS, then surface markers were detected by flow cytometry (FACS Calibur; Becton Dickinson Immnocytometry Systems, CA, USA).

\subsection{Measurement of Cytokine Expression Levels in Blood Cells}

To test whether $f$-Chlorella affected the functional maturation of immunocytes within a short period of time, we examined the number of cytokine containing cells using FACS analysis. This method reveals cytokine producing cell by peering off the surface of lymphocyte, enable to assess the cells in a festival evening, compare than serum cytokine level that correspond to paper tips of post festival [14].

Blood cell suspensions were cultured in phorbol 12-myristate 13-acetate (PMA), ionomycin and bovine serum albumin (BSA) (Sigma CO. Ltd., Mo, USA) for 4 - 5 hrs at $37^{\circ} \mathrm{C}$. Subsequently, the cell suspensions were stained with monoclonal antibodies (Percp-CD3, Percp-CD45, FITC-interferon (IFN)- $\gamma$, PE-interleukin (IL)-4, FITC- IL-1 $\beta$ ) and analyzed by flow cytometry. All antibodies used in this study were purchased from Becton Dickinson Immunocytometry System (CA, USA).

\section{Results}

\subsection{Animal Test}

\subsubsection{Single and Multiple Dose Toxicity Study of Conventional Chlorella and Fermented Chlorella} No deaths or abnormalities of body weight, water and food consumption, or coat condition were observed in the treated mice. Necropsy evaluation of the mice did not reveal any significant differences in thymus, liver, spleen, kidney, adrenal gland and testicle weights between the control group and both conventional Chlorella and f-Chlorella treatment groups, or between males and females.

\subsubsection{Immuno-Compromized Host by Mytomicin-C Treated Mice}

In theanimal model, theimmuno-competencywas reduced in C57BL/6J mice, aged 8-9 weeks,by injecting with Mitomycin-C (MMC) (5mg/kg) to inhibit the bone marrow. Then, Chloreralla samples were administered orally at a dosage of $1 \mathrm{~g} / \mathrm{kg} /$ day for five consecutive days.

\subsubsection{Recovery of Whole Body Weight}

The body weight and thymus weight reduced in bone marrow-suppressed mice, resulting in the reduction of peripheral blood leukocyte to around 40\%. After administered each herbal decoction $1 \mathrm{~g} / \mathrm{kg}$ dairy for 5 days and after 1 week later, their blood were recovered to around $90 \%$ of normal value.

\subsubsection{Recovery of Thymus Weight}

The bone marrow-suppressed mice were administered $f$-Chlorella1g/kg dairy for 5 days, and one week later, 
their blood was withdrawn from their tail vein. The cell count of the peripheral blood is showed in Figure 4. Table 5 shows that the thymus weight decreased to half of normal control after $5 \mathrm{mg} / \mathrm{kg}$ of MMC was injected. However, all the three $f$-Chlorella recovered thymus weight to about $70 \%$ of the control.

\subsubsection{Recovery of $\mathrm{CD}^{+}$Cells and Cytokine Producing Cells}

CD3, CD4 and CD19 cells of MMC treated mice were recovered to almost normal values after the administration of $f$-Chlorella As for the functional recovery, IFN- $\gamma$ and IL-4 producing cells were also recovered the all three decoction, including $f$-Chlorella and a functionally depressive agent of TCM. In cytokine producing cells, IFN- $r$ and IL-4 producing cell were recovered with $f$-Chlorella in all the three $f$-Chlorella tested, cytokine producing cells were recovered with f-Chlorella and even conventional Chlorella (Table 2).

\subsubsection{Recovery of Macrophage Activity, Phagocytosis}

We show that MMC clearly suppressed the phagocytic activity of mice both in number and function. After the treatment of $f$-Chlorella, the mice recovered their phagocytic activity to normal range. With a precise observation, the recovery activity was different between $f$-Chlorella and $f$-Chlorella was the strongest $f$-Chlorella among the four formulae to augment in number and function of phagocytes. On the other hand, the augmentation by f-Chlorella was less than that by Chlorella (Table 3, Figures 2-5).

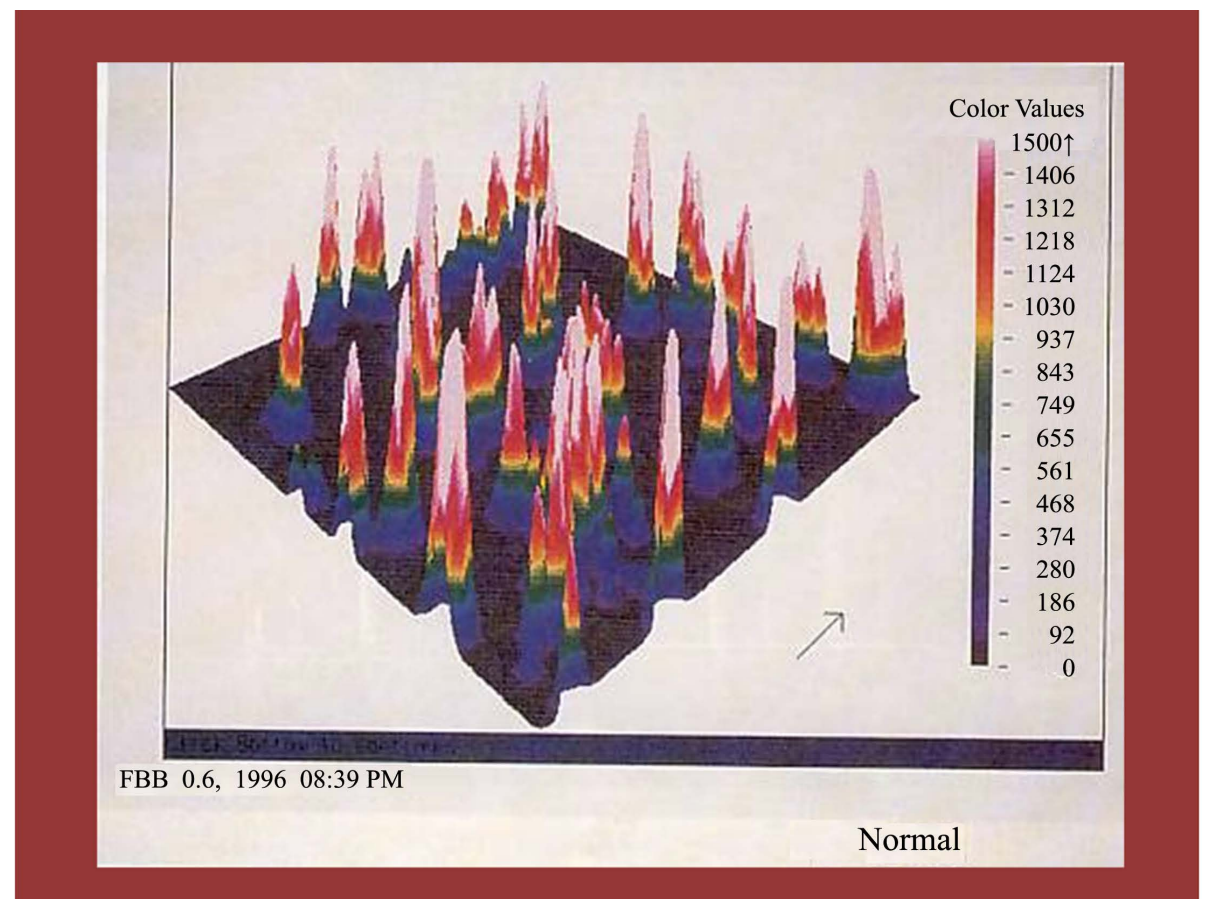

Figure 2. Macrophage pahgocytosis accessed by ACAS system targeting florescent activated latex beads in normal mice We tried to express the effect of peripheral total leukocyte number by individual level of change and plot in the $\mathrm{x}$-axis as in each age. Variations in leukocyte subpopulations in the peripheral blood before and after hot spring hydrotherapy.

Table 2. Plaque forming/antibody secreting cell Supported by Chlorella Derivatives.

\begin{tabular}{cc} 
Group Number & PFC $/ 10^{6}$ Spleen ells \\
\hline 1 Normal Mice & $556 \pm 21$ \\
2 MMC Control & $128 \pm 64$ \\
3 MMC + C. Chlorella & $386 \pm 55^{*}$ \\
4 MMC $+f$-Chlorella & $789 \pm 54^{* *}$ \\
\hline
\end{tabular}

${ }^{*} \mathrm{p}<0.01$ comparing to MMC control. ${ }^{* *} \mathrm{p}<0.05$ comparing to non-fermented formulae. 


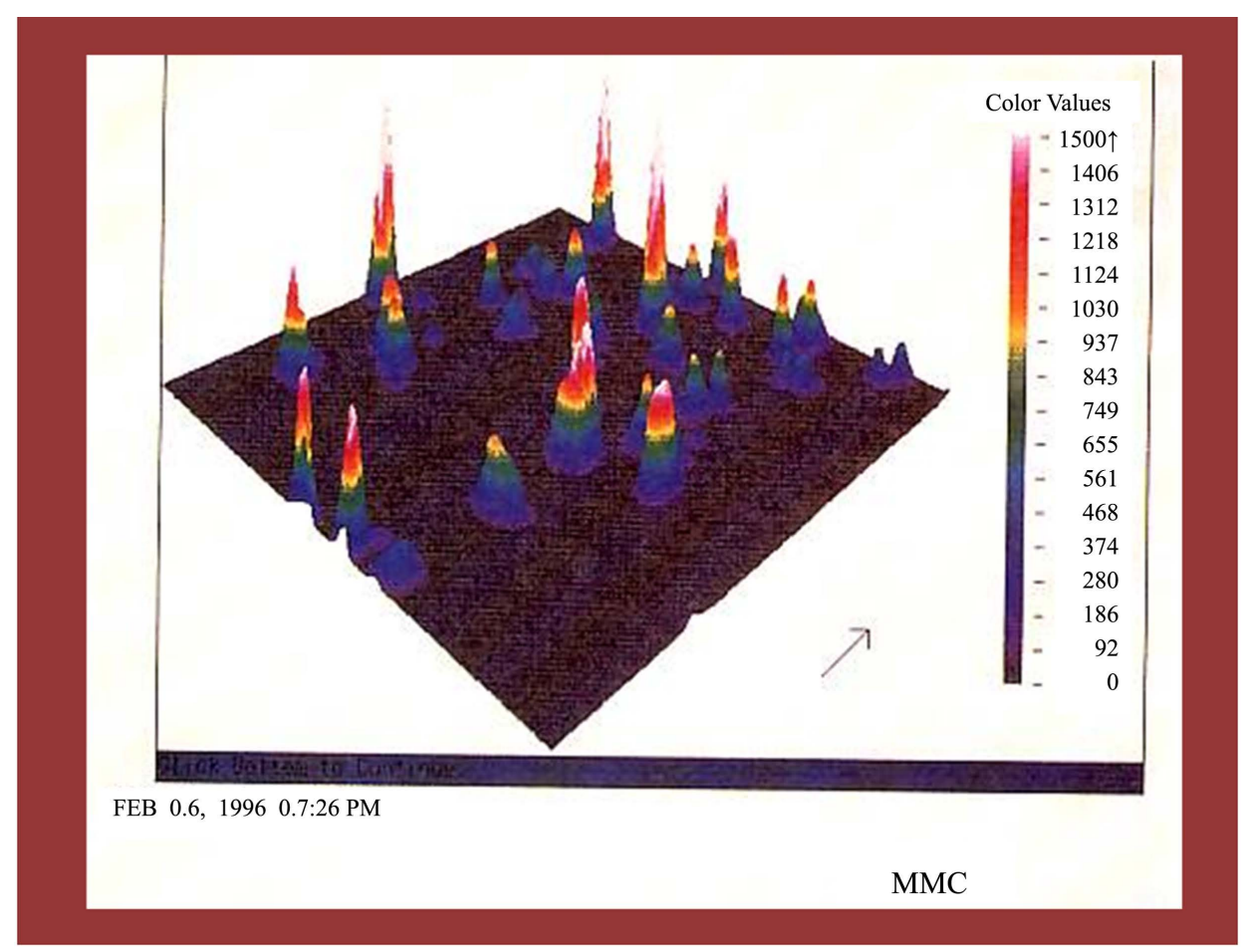

Figure 3. Macrophage pahgocytosis accessed by ACAS system targeting florescent activated latex beads in Mytomicin-C treated mice. We sampled peripheral blood from the 12 volunteers before and after hot spring hydrotherapy, at the same time on each day, in accordance with the consideration of circadian rhythm of leukocyte In this figure, we tried to show the date simply pooled and make mean, then compared.

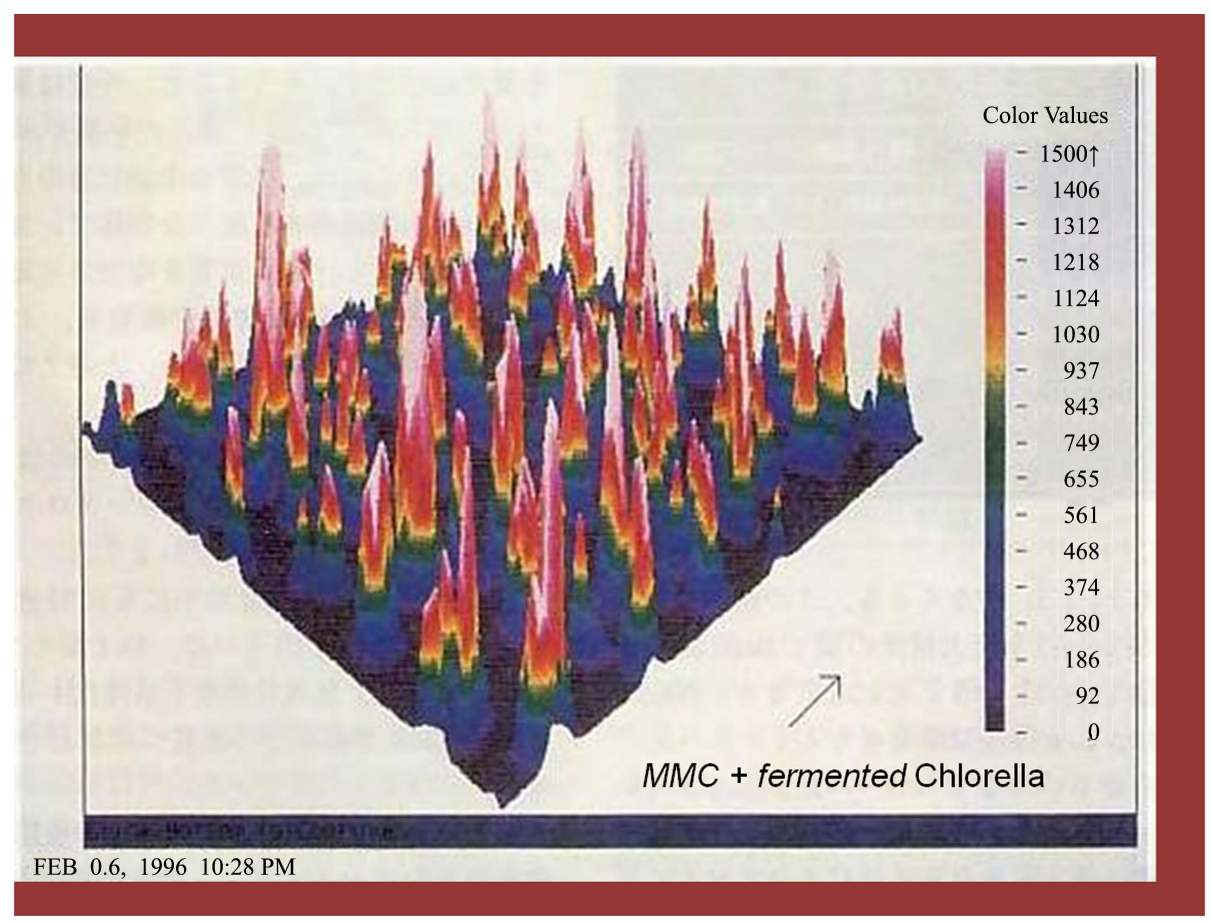

Figure 4. Macrophage pahgocytosis accessed by ACAS system targeting florescent activated latex beads in MMC+ $f$-Chlorella. Each spot were obtained from the calculation comparing relative value from before and after levels in the serum, Catecholamines levels in the peripheral blood. The constitution dependent analysis, the detail change and vector of each change could find from individual data, showing higher value volunteer down regulated much more than lower leveled one. 

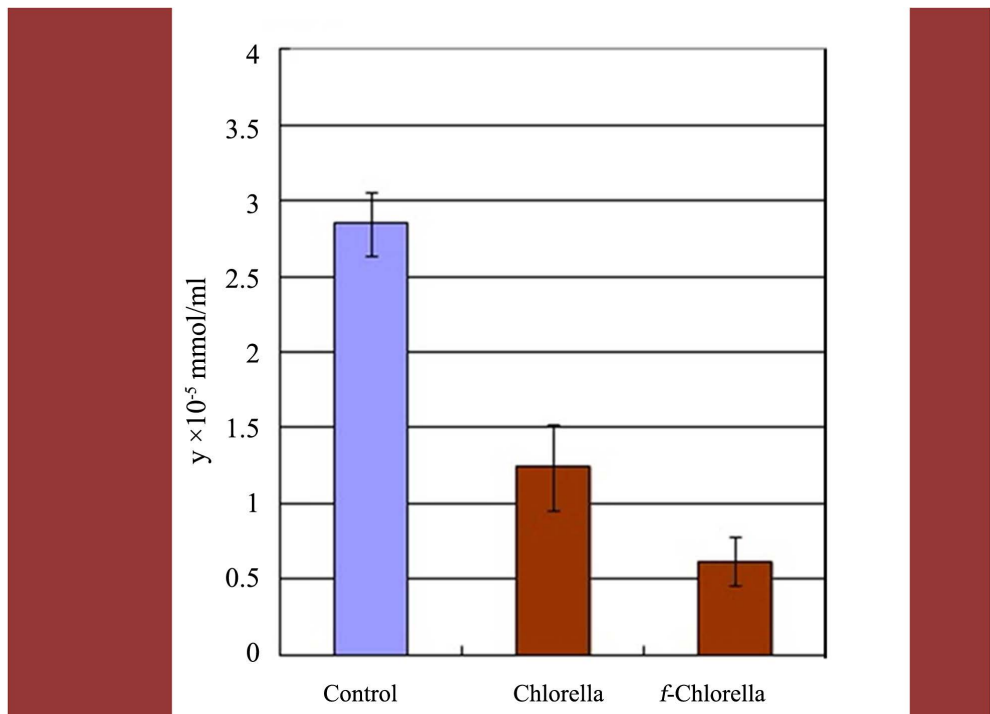

Figure 5. Anti-oxidative effect by Chlorella Derivatives. The analysis of CD positive cells by FCM was measured by gating in the lymphocytes region on the scattered gram. Fig. shows an example analysis. Nonspecific reaction of the PE fluorescence was found in the isotype control.

Table 3. Relative activities of macrophage phagocytosis supported by Chlorella Derivatives.

\begin{tabular}{ccc}
\hline & \multicolumn{3}{c|}{ Phagocytosis } \\
\hline & Positive Cells $/ 10^{6}$ cells \\
\hline Normal & $52(100)$ & High active (\%) \\
MMC & $34(65)$ & $45(100)$ \\
MMC + C.Chlorella & $108(207)$ & $5(11)$ \\
MMC + f-Chlorella & $187(326)$ & $59(131)$ \\
\hline
\end{tabular}

\subsubsection{Recovery of Lymphocyte Activity, Antibody Secreting Cell}

The bone marrow-suppressed mice were administered herbal decoction $f$-Chlorella for five days. One week later, mice were immunized with sheep red blood cells, $\left(2 \times 10^{8}\right.$ cells/mouse $)$ intraperitoneally. Four and six days later, their plague-forming cells (PFC) were developed. The ability of IgM and IgG antibody production was tested method reported by Jerne and Nordin [15]. In this mouse model, MMC did not reduce the antibody forming cells significantly but the tendency was the same as shown in the former section. In this test, B was the most effective than that of A. f-Chlorella was the strongest material to augment antibody secreting cell among the four formulae.

\subsubsection{The amount of Generated Super Oxide Anion}

The amount of generated super oxide anion was calculated in the formula shown above. The generated super oxide anion after one week administration of Agaricus and Chlorella were 2.64 and $1.95 \times 10^{-5} \mathrm{mmol} / \mathrm{ml}$, respectively, whereas that was $2.85 \times 10^{-5} \mathrm{mmol} / \mathrm{ml}$ in control group. The generated super oxide anion after one week administration of herbal medicine, Chlorella were $1.24,1.25$ and $2.88 \times 10^{-5} \mathrm{mmol} / \mathrm{ml}$, respectively. The generated super oxide anion after one week administration of Propolis was $2.55 \times 10^{-5} \mathrm{mmol} / \mathrm{ml}$. All these drugs, except for Chlorella decreased super oxide anion generation after administration for one week in mice.

\section{Clinical Findings}

\subsection{Regulation in Cell Number of Total Leukocyte and Its Subsets}

Leukocyte numbers have been counted one hour before and 15 days after the treatment of hemopoitic formula. 
The cell number measured one hour before the administration was set as $100 \%$. Relative percentage of cell number on the 15th day was calculated. No significant changes were observed in G-group after the administration of both types of Chlorella derivatives. However, significant change was found in L-type group (Table 4).

\subsection{Dividing Subjects into Two Groups, G-Type and L-Type by Granulocyte and Lymphocyte Proportion}

The volunteers were healthy subject, with no drastic change for the total number of leukocytes. However, we tried to check the regulative effect of herbal formulae for two different constitution, G-rich type and L-rich type. Analysis that mixed both groups together showed no significant differences in total leukocyte number except that for f-Chlorella. In G-type group, total number of leukocytes was down regulated by both style of Chlorella. This was a results of the down regulation of major group of leukocyte, granulocyte.

As for the L-type, no significant changes were found after the treatment of both $f$-Chlorella In the L-type group, $f$-Chlorella, on the other hand, increased the tonal leukocyte and granulocyte in number, on the contrary to the down regulation for lymphocytes. To further clarify the influence of hemopoietic formula, we divided the subjects into two groups: the G-type group, who had a granulocyte count over $60 \%$, and the L-type group, who had a lymphocyte count over $40 \%$. In the L-type group, lymphocyte counts tended to decrease on day 15, accompanied by an increase in granulocyte numbers by conventional Chlorella but not by $f$-Chlorella. On the contrary, the granulocyte counts of G-type group tended to decrease on day 15. The decrease of granulocyte count was raised by f-Chlorella on day 15 (Table 5).

\section{Table 4. Constitution dependent regulatory effect by f-Chlorella.}

\begin{tabular}{|c|c|c|c|c|}
\hline & \multicolumn{2}{|c|}{ G-type individual } & \multicolumn{2}{|c|}{ L-type individual } \\
\hline & \multicolumn{2}{|c|}{ Conv. Chlorella } & \multicolumn{2}{|c|}{ f-Chlorella } \\
\hline & Before & After & Before & After \\
\hline Total WBC (x $\left.10^{3} \mu \mathrm{l}\right)$ & 6.66 & 5.95 & 5.82 & 7.04 \\
\hline Lymphocyte (\%) & 24.6 & 265.4 & 34.3 & 43.2 \\
\hline Granulocyte (\%) & 66.5 & 66.4 & 49.8 & 56.8 \\
\hline Neutrophil (\%) & 65.8 & 62.6 & 48.3 & 53.4 \\
\hline Eosinophil (\%) & 1.8 & 2.7 & 2.4 & 4.8 \\
\hline Basophil (\%) & 0.9 & 0.8 & 0.6 & 0.9 \\
\hline
\end{tabular}

Table 5. Constitution dependent regulation of lymphocyte by Chlorella Derivatives.

\begin{tabular}{lcccc} 
& \multicolumn{2}{c}{ G-type individual } & \multicolumn{2}{c}{ L-type individual } \\
\cline { 2 - 5 } CD & \multicolumn{2}{c}{ Conv. Chlorella } & \multicolumn{2}{c}{$f$-Chlorella } \\
\cline { 2 - 5 } CD2 & Before (\%) & After (\%) & Before (\%) & After (\%) \\
CD4 & 632.93 & 77.93 & 64.25 & 78.88 \\
CD8 & 18.76 & 29.52 & 32.15 & 44.15 \\
CD11 & 37.43 & 43.07 & 27.52 & 71.55 \\
CD14 & 72.55 & 71.23 & 65.23 & 0.09 \\
CD16 & 0.04 & 0.04 & 0.08 & 49.45 \\
CD19 & 63.99 & 58.42 & 53.11 & 7.97 \\
CD56 & 8.44 & 8.23 & 8.44 & 2.56 \\
\hline
\end{tabular}




\subsection{Lymphocyte Subsets Showed Significant Variation and Regulation}

After f-Chlorella treatment, cell counts of $\mathrm{CD}_{2}^{+}, \mathrm{CD}^{+}, \mathrm{CD}^{+}, \mathrm{CD} 11 \mathrm{~b}^{+}, \mathrm{CD} 16^{+}, \mathrm{CD} 19^{+}$and $\mathrm{CD} 56^{+}$were tested to evaluate variations in T cells, B cells, macrophages and NK cells. These values were measured one hour before hemopoietic formula and 15 days thereafter. Our results showed that CD2 and CD4 cells were increased by both $f$-Chlorella and SQT. CD11 ${ }^{+}$and $\mathrm{CD} 14^{+}$cell counts, which are closely associated with macrophage activity, increased by $f$-Chlorella in the L-type subjects. In particular, there was a remarkable increase in CD11 ${ }^{+}$cell number on day 15 . $\mathrm{T}$ cell subsets that are closely associated with activity of immature $\mathrm{T}$ cells, $\left(\mathrm{CD2} 2^{+}, \mathrm{CD}^{+}\right.$and $\left.\mathrm{CD}^{+}\right)$, the $\mathrm{CD}^{+}(P<0.05)$ showed an increase with the treatment of $f$-Chlorella 15 days after administration. The number of $\mathrm{CD} 19^{+}$cells, which is closely associated with B cell activity, was not changed by both $f$-Chlorella throughout the trial, neither were the numbers of $\mathrm{CD}_{16}{ }^{+}$and $\mathrm{CD} 6^{+}$cells.

\subsection{Cytokine Producing Cells}

To test whether herbal decoction affected the functional maturation of immunocytes in a short time, we investigated the number of cytokine producing/containing cells by FACS analysis. This method reveals cytokine producing cell number by peering off the surface of lymphocyte, enable to express the number of cells in festival evening, compare than serum cytokine level that correspond to the paper tips of post festival. To determine whether $f$-Chlorella influences functional maturation of immuno-competent cells, levels of IL-1 $\beta$-, IL-4- and IFN- $\gamma$-expressed $\mathrm{T}$ cells were further examined using fluorescence-activated cell sorter analyses. There was a significant increase in the levels of IFN- $\gamma$ and IL-4 containing cells after administration of SQT. The result revealed that IFN- $\gamma$ expression, which increased highly on the 15th day after treatment, was different from the expression of IL- $1 \beta$ and IL-4, those on the other hand, exponentially increased on day 15 after the administration of SQT. The augmentation of cytokine expression was confirmed by a classical method in the lymphoid organ, i.e. antibody-forming cells and plaque-forming cells. Both $f$-Chlorella down-regulated IL- $1 \beta$ producing cells in both G-type and L-type groups (Table 6).

\section{The Complement System-Another Stage for Focusing by Fragmented Polysaccharide}

We would like to focus on the another important factor of immunological component, complement. These protein are compose of at least 9 components. These protein are famous for its defensive activity against infections organisms as in the defense immunity. However, we had found that the complement had worked when we introduced fragmented /fermented polysaccharide as complement activator, so called alternative pathway conjunct to Alternative Medicine. So in this chapter, we would like to show the nature of complement and activated mechanism that lead to the activation of all the physical activities through the augmentation of complement receptor positive structure cells. Activation of the complement system results in a cascade of interactions of these proteins, leading to the generation of products that have important biologic activities and that constitute an important humoral mediator system involved in inflammatory reactions. First, coating of particles, such as bacteria or immune complexes, with certain components of complement facilitates the ingestion of the particle by phagocytic cells (opsonic function of complement). Second, the activation event generates many fission products of complement proteins for which specific receptors exist on a variety of inflammatory cells, such as granulocytes, lymphocytes, and other cells. Binding of these complement-derived products to such receptors results in biologic activities such as chemotaxis and hormone-like activation of cellular functions (inflammatory function of complement).

Table 6. Constitution dependent regulation of cytokine producing cell by Chlorella Derivatives.

\begin{tabular}{cccccc}
\hline & \multicolumn{2}{c}{ G-type individual } & \multicolumn{2}{c}{ L-type individual } \\
\cline { 2 - 5 } Cytokine & \multicolumn{2}{c}{ Conv. Chlorella } & \multicolumn{2}{c}{$f$-Chlorella } \\
\cline { 2 - 5 } & Before (\%) & After (\%) & Before (\%) & After (\%) \\
\hline IFN- $\gamma$ & 6.66 & 5.67 & 3.45 & 5.56 \\
IL-4 & 1.5 & 2.5 & 2.9 & 4.8 & 0.8 \\
IL-1 $\beta$ & 0.7 & 0.9 & 0.7 & 0.7 \\
\hline
\end{tabular}




\subsection{Pathways of Complement Activation and Complement Components}

Activation of complement can occur by two separate pathways: the classical and the alternative pathways. Both pathways lead to a common terminal pathway referred to as the pathway of membrane attack. Twenty plasma proteins, are now known to be constituents of these pathways. These proteins can be divided into functional proteins, which represent the elements of the various pathways, and regulatory proteins, which exhibit control function. The concentration of the proteins in normal human plasma covers a broad range. They are synthesized in the liver but also by cells of the lympho-reticular system, such as lymphocytes and monocytes. Both the classical and the alternative complement pathways can be organized into various operational units: initiation, amplification, and membrane attack. Following an initial recognition event, which leads to initiation of the pathway, an amplification phase takes place that involves the action of proteases and the recruitment of additional molecules; this is followed by a terminal phase of membrane attack during which the cell dies. The recognition unit for the classical pathway, C1, is composed of three separate proteins, Clq, Clr, and Cls. The initiation of this pathway of complement typically involves the reaction of antibody with antigen, which may be soluble or on the surface of a target cell. This antigen-antibody reaction allows the binding of Clq to two or more Fc regions of certain IgG subclasses (IgG1, IgG2, IgG,) or IgM. Activators of the classical pathway. The ultra structure of Clq has been demonstrated by electron microscopy to consist of six subunits similar to a bouquet of six flowers. The central stalks of Clq resemble collagen in primary and secondary structure. Upon binding of one Clq molecule to the Fc regions of two or more antigen-bound antibody molecules, CIr proenzymes are activated. The chemical basis of this activation is the cleavage of a peptide bond by an autocatalytic mechanism, leading to the formation of activated Clr, a protease that subsequently cleaves the proenzyme Cls. Thus, the binding of Clq to an immunoglobulin in complex with the antigen represents the recognition event of the classical pathway, resulting in the activation of Clr and Cls. The final result is the generation of an enzymatically active component, Cls, which will cleave and thereby activate the next proteins in the cascade, leading to amplification of the recognition event.

The enzyme Cls has two physiologic substrates, C4 and C2. C4 is cleaved by Cls into C4a, one of the three anaphylatoxins (molecules that promote increased vascular permeability and smooth muscle contraction), and $\mathrm{C} 4 \mathrm{~b}$, which binds to the target cell surface. Cls also cleaves C2 when C2 is in complex with C4b. Cleavage of $\mathrm{C} 2$ generates $\mathrm{C} 2 \mathrm{~b}$, which is released, and C2a, which remains bound to C4b. The bimolecular complex C4b, 2a is a protease that cleaves C3 and therefore is called C3 convertase. Cleavage of C3 by the C3 convertase generates two important biologically active peptides, C3a (another anaphylatoxin) and cab, which attaches to target cell surfaces and can bind to C5. C5, when in complex with C3b, can be cleaved by the C3 convertase (then referred to as C5 convertase). The C5 convertase hydrolyzes C5, which generates the C5a anaphylatoxin and C5b. $\mathrm{C} 5 \mathrm{~b}$ is the nucleus for the formation of the membrane attack complex. Immediately following their generation, C3b and C4b exhibit a unique transient ability to covalently bind to target cells ("metastable binding site"). This property has reentry been shown to be due to an intramolecular thioester bond that is present between the sulfhydryl group of a cysteine residue and the gamma carbonyl group of a glutamine residue on C3 and C4. Upon activation of $\mathrm{C} 3$ or $\mathrm{C} 4$, this thioester becomes highly reactive and can react with a cell surface hydroxyl or amino group. This results in the covalent attachment of $\mathrm{C} 3 \mathrm{~b}$ or $\mathrm{C} 4 \mathrm{~b}$ to the target cell. An additional function of the thioester bond is its hydrolysis by water, occurring during activation of the alternative pathway as described below.

The alternative pathway can be activated when a molecule of C3b is bound to a target cell. This C3b molecule combines with the plasma protein Factor B, which is a zymogen, and which, when bound to C3b, can be activated by the plasma protein Factor $\mathrm{D}$ by cleavage into two fragments, $\mathrm{Ba}$ and $\mathrm{Bb}$. The $\mathrm{Bb}$ fragment, which contains the active enzymatic site, remains bound to C3b, as C3b, Bb. This complex, like C4b, 2a in the classical pathway, is a $\mathrm{C} 3$ convertase $(\mathrm{C} 3 \mathrm{~b}$; $\mathrm{Bb}$ ); it is stabilized by the binding of another plasma protein, properdin. Thus, the alternative pathway used to be called the properdin pathway. The presence of a single molecule of C3b generates many molecules of $\mathrm{C} 3 \mathrm{~b}, \mathrm{Bb}$, resulting in a tremendous amplification. The $\mathrm{C} 3$ convertase $(\mathrm{C} 3 \mathrm{~b}, \mathrm{Bb})$ cleaves $\mathrm{C} 3$, thereby generating more molecules of $\mathrm{C} 3 \mathrm{~b}$, which can combine with other molecules of factor B to give more molecules of cab, $\mathrm{Bb}$, which can, in turn, cleave more molecules of $\mathrm{C} 3$. Therefore, the central feature of the alternative pathway is a positive feedback loop that amplifies the original recognition event. As in the classical pathway, attachment of many C3b molecules to the target cell -will allow binding of C5 and its cleavage into $\mathrm{C} 5 \mathrm{a}$ and $\mathrm{C} 5 \mathrm{~b}$ by the enzyme $\mathrm{C} 3 \mathrm{~b}, \mathrm{Bb}$, now referred to as $\mathrm{C} 5$ convertase. 
Owing to the potential of this positive feedback loop to rapidly use up Factor B and C3, the positive feedback must be carefully regulated. There are two important regulatory proteins in plasma. The first protein, Factor $\mathrm{H}$ (formerly referred to as PIH), competes with Factor B for binding to C3b and also dissociates C3b, Bb into C3b and $\mathrm{Bb}$. The second control protein, Factor I (formerly referred to as C3b in activator), cleaves C3b that is bound to Factor $\mathrm{H}$ or to a similar protein found on the surface of the host cell. The resulting cleaved C3b, termed iC3b, can no longer form a C3 convertase. The action of these two control proteins prevents the consumption of Factor $\mathrm{B}$ and C3 in plasma; in addition, these two proteins in activate C3b, Bb on host cell surfaces. In contrast, surfaces of many target cells, such as bacteria and other microorganisms, protect $\mathrm{C} 3 \mathrm{~b}$, Bb from in activation by Factors $\mathrm{H}$ and I. This protection allows the positive feedback loop to proceed on the surface of the target cell, leading to the activation of the pathway and subsequent cell death. In other words, the alternative pathway is activated by those substances that prevent the inactivation of the positive feedback loop enzyme C3b, Bb. A substance is therefore treated as "foreign" if it restricts the action of Factors H and I and allows the positive feedback loop to continue.

The chemical structures on surfaces of particles and cells responsible for activation or non-activation of the alternative pathway have not been identified. There is some evidence that carbohydrate moieties are involved, particularly sialic acid. The alternative pathway protein(s) responsible for the recognition of these structures also remains to be determined. As pointed out earlier, the activation of the alternative pathway requires a C3b molecule bound to the surface of a target cell. An intriguing question is, "Where does the critical first cab molecule come from?”. Although it can be provided by the C3 convertase of the classical pathway or by cleavage of C3 by plasmin and certain bacterial and other cellular proteases, the alternative pathway can generate this first C3b molecule without these proteases. The intramolecular thioester, which is highly reactive in nascent C3b and is responsible for the covalent attachment to targets, is also accessible in native C3 to water molecules. Thus, spontaneous hydrolysis of the thioester bond occurs constantly in plasma at a low rate. The C3 molecules in which the thioester bond has been hydrolyzed behave like C3b, although the C3a domain has not been removed. C3 with a hydrolyzed thioester is called C3 (H20) or C3b-like C3. It can bind Factor B and allow Factor D to activated Factor B, which results in formation of a fluid-phase C3 convertase, C3, Bb. This enzyme is continuously formed and produces C3b molecules that can randomly attach to cells. Although these C3b molecules will be rapidly inactivated on host cells by Factors $\mathrm{H}$ and I, they will start the positive feedback loop on foreign surfaces, as outlined previously. In other words, the alternative pathway is constantly activated at a low rate, but amplification with subsequent cell death occurs only on foreign particles.

\subsection{Activated Products of Complement and Their Biological Activity}

Activation of either the alternative or the classical pathway results in the generation of many important peptides involved in inflammatory responses. The anaphylaxis increase of vascular permeability degranulation of mast cells and basophils with release of histamine Degranulation of eosinophils Aggregation of platelets opsonization of particles and solubilization of immune complexes with subsequent facilitation of phagocytosis Release of neutrophils from bone marrow resulting in leukocytosis Smooth muscle contraction Increase of vascular permeability Smooth muscle contraction Increase of vascular permeability Degranulation of mast cells and basophils with release of histamine Degranulation of eosinophils Aggregation of platelets Chemotaxis of basophils, eosino phils, neutrophils, and monocytes Release of hydrolytic enzymes from neutrophils Chemotaxis of neutrophils Release of hydrolytic enzymes from neutrophils Inhibition of migration and indulation of spreading of monocytes and macrophages latoxinsna C3a, C4a, and C5a are derived from the enzymatic cleavage of C3, C4, and C5 respectively. Historically, C3a and C5a were defined as factors derived from activated serum possessing spasmogenic activity. The anaphylatoxins are now recognized as having many additional biologic functions. Both C3a and C5a are known to induce the release of histamine from mast cells and basophils (chapter 20A). As shown in Figure 6 both anaphylatoxins cause smooth muscle contraction and induce the release of vasoactive amines, which cause an increase in vascular permeability.

The effect of $\mathrm{C} 5 \mathrm{a}$ anaphylatoxin on neutrophils is of considerable importance in the inaammatory response. Not only can C5a induce neutrophil aggregation, but this anaphylatoxin appears to be the main chemotactic peptide generated by activation of either complement pathway. In vitro, nanomolar concentrations of C5a will induce the unidirectional movement of neutrophils. Other inflammatory cells, such as monocytes, eosinophils, basophils, and macrophages, have also been shown to exhibit a chemotactic response to C5a. The removal of the 


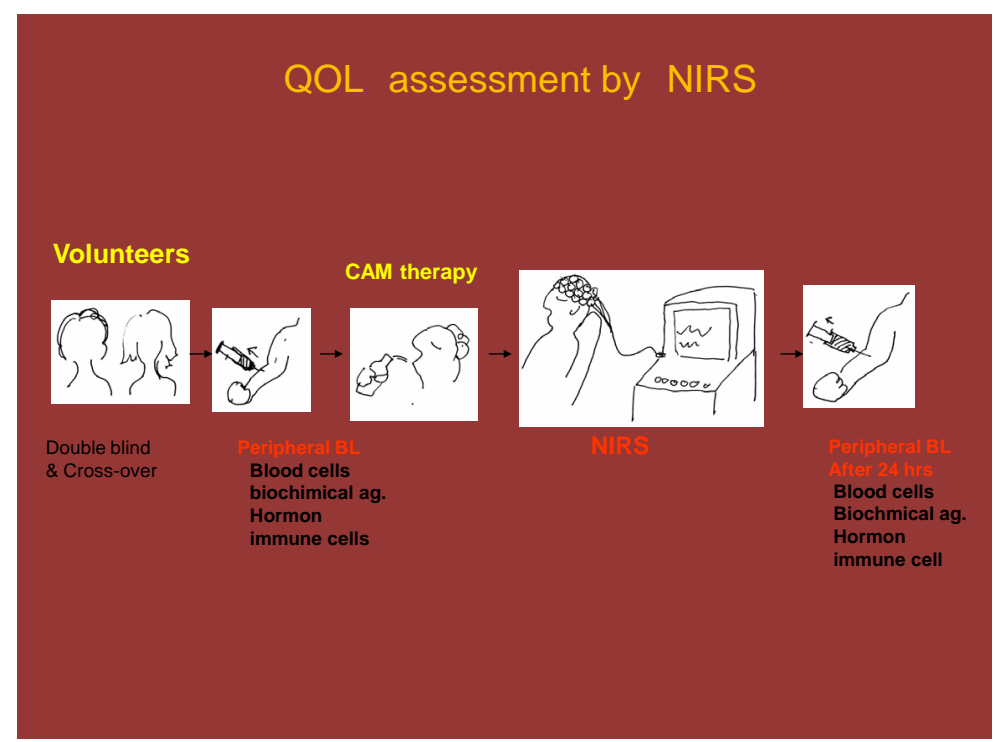

Figure 6. Experimental Design for Assessing CAM Therapy. The analysis of $\beta_{2}$-AR expressing cells and CD positive cells by FCM was measured by gating in the lymphocytes region on the scattered gram. Figure shows an example analysis.

carboxy-terminal arginine from C5a by serum carboxy peptidase $\mathrm{N}$, generating C5a-des-arg, inactivates the spasmogen, yet restoration of full chemotactic activity of C5a-des-are may occur in the presence of serum. Therefore, C5a-desarg may also be responsible for in vivo neutrophil chemotactic activity.

As described earlier, the cleavage of C3 by either the alternative or the classical C3 convertases results in the production of two major split products, the C3a anaphylatoxin and cab. The larger C3b fragment can serve as an opsonin (promoter of phagocytosis) by binding to a target through the thioester mechanism. This renders the particle or cell immediately susceptible to ingestion by a variety of phagocytic cells that carry specific receptors for C3b.

Many recent observations point to additional roles for complement fragments in regulating the activity $9 \mathrm{f}$ cells of the immune system. These observations include the presence of receptors on lymphocytes for various complement proteins, including C3 split products and Factor H, affecting B and T cell function. This is an important area for future research (Figures 7-9).

\section{Cardio-Vascular Disease}

Daily consumption of the Chlorella extract of Chlorella. Pyrenoidosa significantly reduces the serum levels of total cholesterol, LDL-C, and triglyceride (TG) and oxidative stress in hyper lipidemic patients. Therefore, this extract could be considered as a potential agent for treatment of dyslipidemia and prevention of atherosclerosis development.

\section{Discussion}

Our investigation clarified how hemopoitic formula, also known as tonic agent and Bu-Ji, influenced the immune system (e.g. leukocyte, granulocyte and lymphocyte subsets in particular).

We quantified CD positive cell counts as indicators of T cells, B cells, macrophages and NK cells. For qualitative and quantitative evaluation, we examined the cytokine expression levels, and directly measured the expression levels of cytokine-containing cells in peripheral blood, eliminating possible artificial factors that could arise from culturing in test tubes or changes in net value by cartelization. To avoid any possible influence from the circadian rhythm, we obtained the whole blood from all donors at the same time.

In this investigation, we confirmed that $f$-Chlorella quantitatively and qualitatively regulated leukocytes, granulocytes, lymphocytes and their subsets. The increase of $\mathrm{CD}^{+}, \mathrm{CD}^{+}, \mathrm{CD}^{+}, \mathrm{CD} 11 \mathrm{~b}^{+}, \mathrm{CD} 16^{+}, \mathrm{CD} 19^{+}$and 


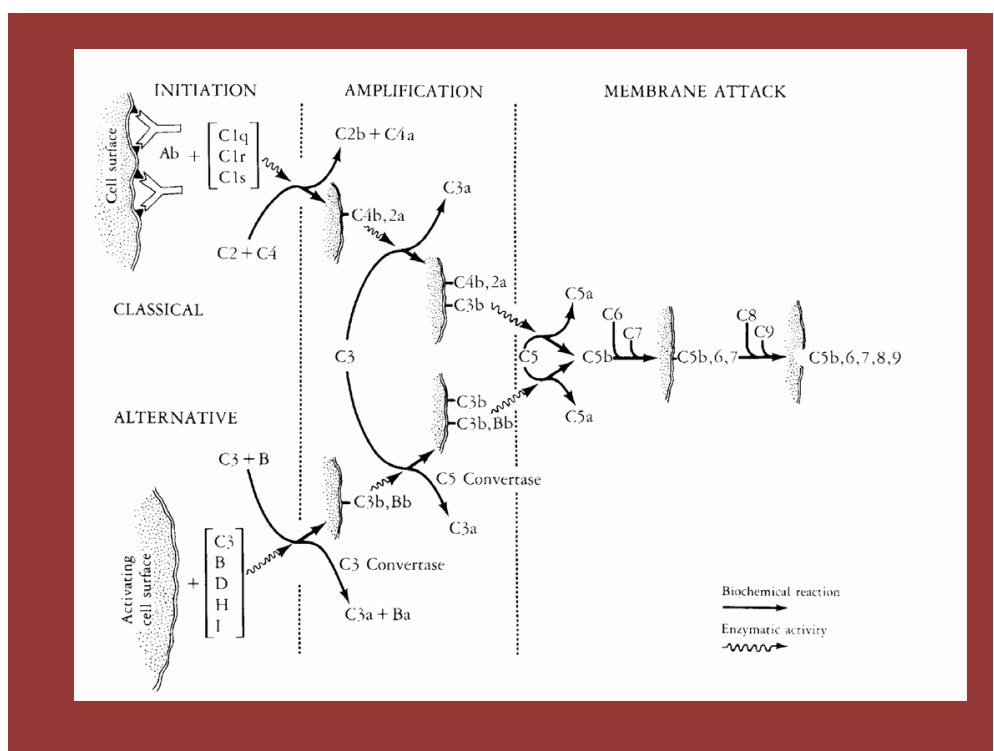

Figure 7. Complement Cascade from Start to the Final. An East and Lactobacilli can degradate the macromolecular substances to low molecular one to get their energy. This procedure had been so called fermentation, This process is good for storage and finding new taste for human being as well as other creatures. This product was to find to get through intestinal barrier and activated the complement component that was succeeded to augment receptor positive physiological cell scattered around the each organ including immunological competent organ.

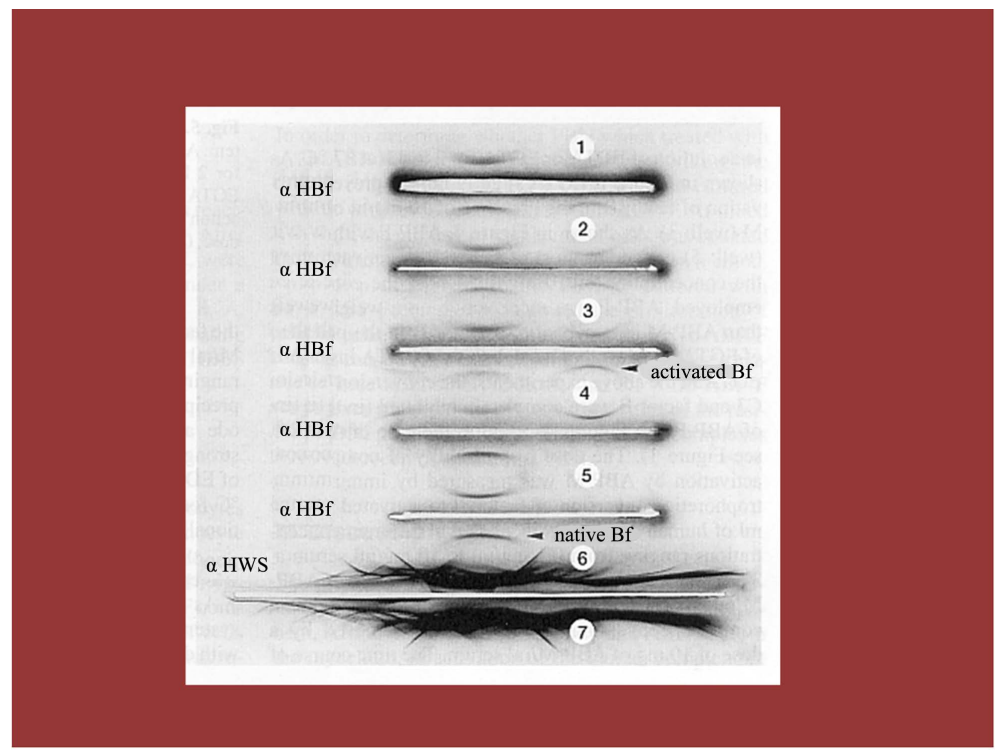

Figure 8. An Immuno Electrophoresis to Show Direct Evidence of Activated Complement Fragment Administrating f-Chlorella. The analysis of $\beta_{2}$-AR receptor expressing cells and CD positive cells by FCM was measured by gating in the lymphocytes region on the scattered gram. Figure shows an example analysis.

$\mathrm{CD}^{+} 6^{+}$cell counts as well as the levels of IL- $1 \beta$, IL-4 and IFN- $\gamma$ in blood cells suggested that hemopoitic formula might enhance the activities of humoral and cellular immunities, as well as NK cells. We also observed that levels of cytokine producing cells, in particular, increased rather than CD-positive lymphocytes, showing 


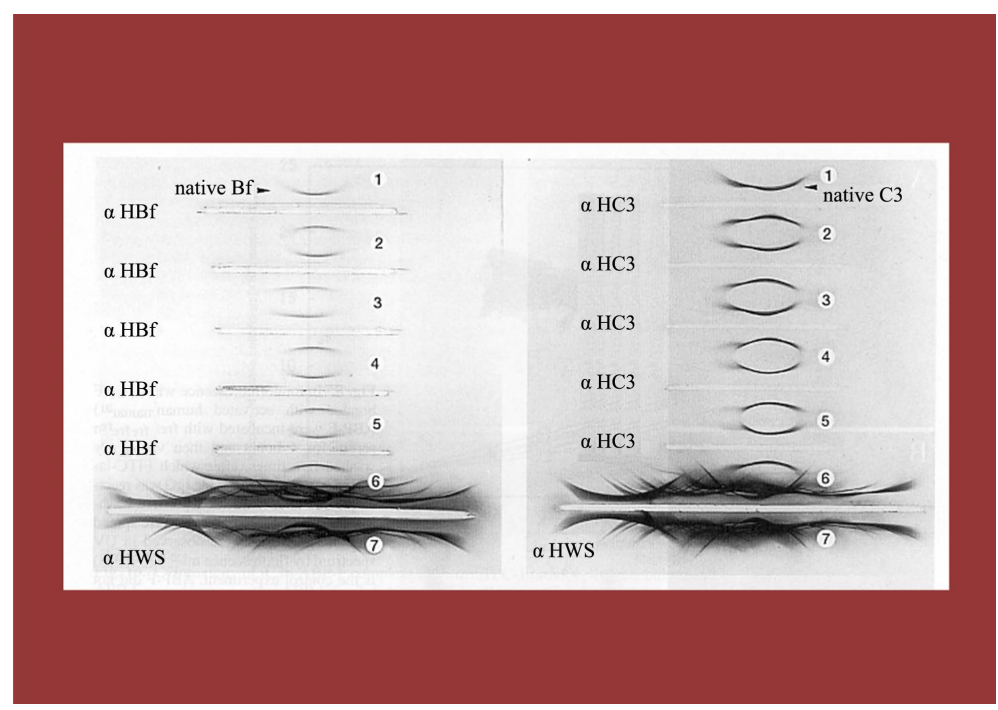

Figure 9. An Immuno Electrophoresis to Show Direct Evidence of Activated Complement Fragment Administrating f-Chlorella. Time interval of blood sampling between before and after hot-spring hydrotherapy was approximately 24 hours. Measurements of the total and differential leukocyte counts and 3 catecholamines levels in the peripheral blood.

that $f$-Chlorella augmented lymphocyte production qualitatively than quantitatively. Moreover, $f$-Chlorella activated both CD11b cells and IL- $1 \beta$ producing cells, suggesting the activation of phagocyte cells both in number and in function. Consequently, these data further demonstrated that $f$-Chlorella acted in macrophages in the same manner as Mycobacterium tuberculosis that has cell walls constructed of waxy substances [13].

In previous reports about hot-spring hydrotherapy and acupuncture, we had proposed that immune system regulation was an important factor for evaluating CAM. Since other substances, such as endotoxin and waxy substances from Mycobacterium tuberculosis, similar to proplis, were known for augmenting host immune responses. This time, we decided to focus solely on propolis. A possible explanation for immune enhancement could be the activation of the circular system and/or autonomic nervous system, although the details of the mechanism remain unclear. Further research regarding to the mechanism was necessary.

Abo et al. reported that granulocyte count was increased $f$-Chlorella the excitation of the sympathetic nervous system, while lymphocyte count was increased by excitation of parasympathetic nervous system [11] [12]. Our data also showed that granulocyte count was decreased in subjects with a high granulocyte count, while lymphocyte count was increased in the same subjects [16]-[20]. The lymphocyte count, however, was decreased in subjects with a high lymphocyte level, while granulocyte count was increase in the same subjects. In other words, the subjects dominated $f$-Chlorella the sympathetic nerve could release stress, whereas the sympathetic activity of subjects who were dominated parasympathetic nerve might be excited by hemopoietic formula. This way, the cell counts appeared to converge at appropriate levels after hemopoietic formula. Finally, in order to determine whether the elevation of leukocyte counts resulted from an infection triggered by hemopoitic formula or not, the subjects were followed up for 8 days after the last administration of hemopoitic formula [21]-[30]. During that period, we could not observe any infectious signs such as pyodermitis, fever, or enhancement of C-Reactive Protein (CRP). The value of CRP was $0.57 \mathrm{~g} / \mathrm{dl}$ to $1.23 \mathrm{~g} / \mathrm{dl}$ in our subjects, suggesting very mild inflammatory responses, which showed that hemopoitic formula did not cause infection. Since the meridian might influence cells throughout the body and might pass through every organ system, hemopoitic formula stimulation might provide maximum benefits without dangerous side effects. As an immune-augmentation system, hemopoietin formulae merit health investigation as a possible treatment for acquired immune-deficiency system. The other failure especially for the senile required throughout the world [31]-[39].

\section{References}

[1] Kitada, Y., Wan, W., Matsui, K., Matsui, K., Shimizu, S. and Yamaguchi, N. (2000) Regulation of Peripheral White 
Blood Cells in Numbers and Functions through Hot-Spring Bathing during a Short Term-Studies in Control Experiments. Journal of Japanese Society Balneology Climatology Physiological Medicine, 63, 151-164.

[2] Yamaguchi, N., Takahashi, T., Sugita, T., Ichikawa, K., Sakaihara, S., Kanda, T., Arai, M. and Kawakita, K. (2007) Acupuncture Regulates Leukocyte Subpopulations in Human Peripheral Blood. Evidence-Based Complementary and Alternative Medicine, 4, 447-453. http://dx.doi.org/10.1093/ecam/nel107

[3] Suzuki, S., Toyabe, S., Moroda, T., Tada, T., Tsukahara, A. and Iiai, T. (1997) Circadian Rhythm of Leukocytes and Lymphocytes Subsets and Its Possible Correlation with the Function of the Autonomic Nervous System. Clinical Experimental Immunology, 110, 500-508. http://dx.doi.org/10.1046/j.1365-2249.1997.4411460.x

[4] Yamaguchi, N., Kawada, N., Ja, X.S., Okamoto, K., Okuzumi, K., Chen, R. and Takahashi, T. (2014) Overall Estimation of Anti-Oxidant Activity by Mammal Macrophage. Open Journal of Rheumatology and Autoimmune Diseases, 4, 13-21. http://dx.doi.org/10.4236/ojra.2014.41002

[5] Hamada, M. and Yamaguchi, N. (1988) Effect of Kanpo Medicine, Zyuzentaihoto, on the Immune Reactivity of Tumor-Bearing Mice. Journal of Ethnopharmacology, 24, 311-320. http://dx.doi.org/10.1016/0378-8741(88)90160-2

[6] Tu, C.C., Li, C.S., Liu, C.M. and Liu, C.C. (2011) Comparative Use of Biomedicine and Chinese Medicine in Taiwan: Using the NHI Research Database. Journal of Alternative and Complementary Medicine, 17, 339-346. http://dx.doi.org/10.1089/acm.2010.0200

[7] Yamaguchi, N., Chen, R., Okamoto, K., Takei, T., Tsubokawa, M., Sakamoto, D., Jia, X.S., Wenhan, W.W. and Murayama, T. (2013) Quantitative Regulation of Peripheral Leukocyte by Light Exercise and Tailored Scale for Assessment. Open Journal of Immunology, 3, 175-183. http://dx.doi.org/10.4236/oji.2013.34022

[8] Yamaguchi, N., Wenhan, N., Wan, W., Sakamoto, D., Nurmuhammad, A., Matsumoto, K., Takei, T., Okuzumi, K., Murayama, T. and Takahashi, T. (2013) Regulative Effect for Natural Killer Cell by Hot Spring HydrotherapyQuantitative and Qualitative Discussion. Open Journal of Immunology, 3, 201-209. http://dx.doi.org/10.4236/oji.2013.34025

[9] Navo, M.A., Phan, J. and Vaughan, C. (2004) An Assessment of the Utilization of Complementary and Alternative Medication in Women with Gynecologic or Breast Malignancies. Journal of Clinical Oncology, 22, 671-677. http://dx.doi.org/10.1200/JCO.2004.04.162

[10] Murayama, T., Yamaguchi, N., Iwamoto, K. and Eizuru, Y. (2006) Inhibition of Ganciclovir-Resistant Human Cytomegalovirus Replication by Kampo (Japanese Herbal Medicine). Antiviral Chemistry \& Chemotherapy, 17, 11-16. http://dx.doi.org/10.1177/095632020601700102

[11] Abo, T., Kawate, T., Itoh, K. and Kumagai, K. (1981) Studies on the Bioperiodicity of the Immune Response. I. Circadian Rhythms of Human T, B and K Cell Traffic in the Peripheral Blood. Journal of Immunology, 126, 1360-1363.

[12] Abo, T. and Kumagai, T. (1978) Studies of Surface Immunoglobulins on Human B Lymphocytes. Physiological Variations of Sig+ Cells in Peripheral Blood. Clinical Experimental Immunology, 33, 441-452.

[13] Landmann, R.M.A., Muller, F.B., Perini, C., Wesp, M., Erne, P. and Buhler, F.R. (1984) Changes of Immunoregulatory Cells Induced by Psychological and Physical Stress: Relationship to Plasma Catecholamines. Clinical Experimental Immunology, 58, 127-135.

[14] Iio, A., Ohguchi, K., Naruyama, H., Tazawa, S., Araki, Y., Ichihara, K., Nozawa, Y. and Ito, M. (2012) Ethanolic Extract of Brazilian Red Propolis ABCA1 Expression and Promote Cholesterol Effulux from THP-1 Macrophage. Phytomedicine, 19, 383-388. http://dx.doi.org/10.1016/j.phymed.2011.10.007

[15] Jerne, N.K. and Nordin, A.A. (1963) Plaque Formation in Agar by Single Antibody Producing Cells. Science, 140, 405-408. http://dx.doi.org/10.1126/science.140.3565.405

[16] Jyumonji, N. and Fujii, Y. (1993) A New Assay for Delayed-Type Hypersensitivity in Vitro Detection F-CHLORELLA. The Macrophage Migration by Boyden Chamber. The Journal of Kanazawa Medical University, 18, 198-203.

[17] Yamaguchi, N., Shimizu, S. and Izumi, H. (2004) Hydrotherapy Can Modulate Peripheral Leukocytes: An Approach to Alternative Medicine. Advances in Experimental Medicine and Biology, 546, 239-251. http://dx.doi.org/10.1007/978-1-4757-4820-8_18

[18] Murayama, T., Yamaguchi, N., Matsuno, H. and Eizuru, Y. (2004) In Vitro Anti-Cytomegalovirus Activity of Kampo (Japanese Herbal) Medicine. Evidence-Based Complementary and Alternative Medicine, 1, 285-289.

[19] Abe, S., Yamaguchi, N., Tansho, S. and Yamaguchi, H. (2005) Preventive Effects of Juzen-taiho-to on Infectious Disease. In: Haruki, Y. and Isao, S., Eds., Juzen-taiho-to (Shi-Quan-Da-Bu-Tang): Scientific Evaluation and Clinical Applications, Traditional Herbal Medicines for Modern Times, CRC Press, Boca Raton.

[20] Nakano, S., Noguchi, T., Takekoshi, H., Suzuki, G. and Nakano, M. (2005) Maternal-Fetal Distribution and Transfer of Dioxins in Pregnant Women in Japan, and Attempts to Reduce Maternal Transfer with Chlorella (Chlorella pyrenoidosa) Supplements. Chemosphere, 61, 1244-1255. http://dx.doi.org/10.1016/j.chemosphere.2005.03.080 
[21] Otsuki, T., Shimizu, K., Iemitsu, M. and Kono, I. (2011) Salivary Secretory Immunoglobulin a Secretion Increases after 4-Weeks Ingestion of Chlorella-Derived Multicomponent Supplement in Humans: A Randomized cross over Study. Nutrition Journal, 10, 91. http://dx.doi.org/10.1186/1475-2891-10-91

[22] Otsuki, T., Shimizu, K., Iemitsu, M. and Kono, I. (2012) Chlorella Intake Attenuates Reduced Salivary SIgA Secretion in Kendo Training Camp Participants. Nutrition Journal, 11, 103.

[23] Hasegawa, T., Ito, K., Ueno, S., Kumamoto, S., Ando, Y., Yamada, A., Nomoto, K. and Yasunobu, Y. (1999) Oral Administration of Hot Water Extracts of Chlorella vulgaris Reduces IgE Production against Milk Casein in Mice. International Journal of Immunopharmacology, 21, 311-323. http://dx.doi.org/10.1016/S0192-0561(99)00013-2

[24] Hsu, H.Y., Jeyashoke, N., Yeh, C.H., Song, Y.J., Hua, K.F. and Chao, L.K. (2010) Immunostimulatory Bioactivity of Algal Polysaccharides from Chlorella pyrenoidosa Activates Macrophages via Toll-Like Receptor 4. Journal of Agricultural and Food Chemistry, 58, 927-936. http://dx.doi.org/10.1021/jf902952z

[25] Nakano, S., Takekoshi, H. and Nakano, M. (2010) Chlorella pyrenoidosa Supplementation Reduces the Risk of Anemia, Proteinuria and Edema in Pregnant Women. Plant Foods for Human Nutrition, 65, 25-30. http://dx.doi.org/10.1007/s11130-009-0145-9

[26] Soontornchaiboon, W., Joo, S.S. and Kim, S.M. (2012) Anti-Inflammatory Effects of Violaxanthin Isolated from Microalga Chlorella ellipsoidea in RAW 264.7 Macrophages. Biological and Pharmaceutical Bulletin, 35, 1137-1144. http://dx.doi.org/10.1248/bpb.b12-00187

[27] Vecina, J.F., Oliveira, A.G., Araujo, T.G., Baggio, S.R., Torello, C.O., Saad, M.J. and Queiroz, M. (2014) Chlorella Modulates Insulin Signaling Pathway and Prevents High-Fat Diet-Induced Insulin Resistance in Mice. Life Sciences, 95, 45-52. http://dx.doi.org/10.1016/j.lfs.2013.11.020

[28] Cherng, J.Y. and Shih, M.F. (2005) Preventing Dyslipidemia by Chlorella pyrenoidosa in Rats and Hamsters after Chronic High Fat Diet Treatment. Life Sciences, 76, 3001-3013. http://dx.doi.org/10.1016/j.lfs.2004.10.055

[29] Ryu, N.H., Lim, Y., Park, J.E., Kim, J., Kim, J.Y., Kwon, S.W. and Kwon, O. (2014) Impact of Daily Chlorella Consumption on Serum Lipid and Carotenoid Profiles in Mildly Hypercholesterolemic Adults: A Double-Blinded, Randomized, Placebo-Controlled Study. Nutrition Journal, 13, 57. http://dx.doi.org/10.1186/1475-2891-13-57

[30] Mizoguchi, T., Takehara, I., Masuzawa, T., Saito, T. and Naoki, Y. (2008) Nutrigenomic Studies of Effects of Chlorella on Subjects with High-Risk Factors for Lifestyle-Related Disease. Journal of Medicinal Food, 11, 395-404. http://dx.doi.org/10.1089/jmf.2006.0180

[31] Jong, Y.C. and Mei, F.S. (2005) Potential Hypoglycemic Effects of Chlorella in Streptozotocin-Induced Diabetic Mice. Life Sciences, 77, 980-990. http://dx.doi.org/10.1016/j.lfs.2004.12.036

[32] Dauchet, L., Amouyel, P., Hercberg, S. and Dallonggeville, J. (2006) Fruit and Vegetable Consumption and Risk of Coronary Heart Disease: A Meta-Analysis of Cohort Studies. The Journal of Nutrition, 136, 2588-2593.

[33] Shimbo, M., Kawagishi, H. and Yokogoshi, H. (2005) Erinacine A Increases Catecholamine and Nerve Growth Factor Content in the Central Nervous System of Rats. Nutrition Research, 25, 617-623. http://dx.doi.org/10.1016/j.nutres.2005.06.001

[34] Kawagishi, H. and Zhuang, C. (2008) Compounds for Dementia from Hericium erinaceum. Drug of the Future, 33, 149-155. http://dx.doi.org/10.1358/dof.2008.033.02.1173290

[35] Mizuno, M., Morimoto, M., Minato, K. and Tsuchida, H. (1998) Polysaccharides from Agaricus blazei Stimulate Lymphocyte T-Cell Subsets in Mice. Bioscience, Biotechnology, and Biochemistry, 62, 434-437. http://dx.doi.org/10.1271/bbb.62.434

[36] Nakamura, T., Matsugo, S., Uzuka, Y., Matsuo, S. and Kawagishi, H. (2004) Fractionation and Anti-Tumor Activity of the Mycelia of Liquid-Cultured Phellinus linteus. Bioscience, Biotechnology, and Biochemistry, 68, 868-872. http://dx.doi.org/10.1271/bbb.68.868

[37] Lindequist, U., Niedermeyer, T.H.J. and Jülish, W.D. (2005) The Pharmacological Potential of Mushrooms. EvidenceBased Complementary and Alternative Medicine, 2, 285-299. http://dx.doi.org/10.1093/ecam/neh107

[38] Yamaguchi, N., Ueyama, T., Amat, N., Yimit, D., Hoxur, P., Sakamoto, D., Katoh, Y., Watanabe, I. and Su, S.Y. (2015) Bi-Directional Regulation by Chinese Herbal Formulae to Host and Parasite for Multi-Drug Resistant Staphylococcus aureus in Humans and Rodents. Open Journal of Immunology, 4, $18-32$. http://dx.doi.org/10.4236/oji.2015.51003

[39] Shimizu, S., Kitada, H., Yokota, H., Yamakawa, J., Murayama, T., Sugiyama, K., Izumi, H. and Yamaguchi, N. (2002) Activation of the Alternative Complement Pathway by Agaricus blazei Murill. Phytomedicine, 9, 536-545. http://dx.doi.org/10.1078/09447110260573047 